\title{
Influence of basic dopants on the activity of
}

\section{$\mathrm{Ru} / \mathrm{Pr}_{6} \mathrm{O}_{11}$ for hydrogen production by ammonia}

\section{decomposition}

Katsutoshi Nagaoka a,b,c,*, Takaaki Eboshi ${ }^{\text {a }}$, Naruhiko Abe a, Shin-ichiro Miyahara a, Kyoko Honda $^{\text {a }}$, and Katsutoshi Sato a,b

${ }^{a}$ Department of Applied Chemistry, Faculty of Engineering, Oita University, 700 Dannoharu, Oita 870-1192, Japan

${ }^{\mathrm{b}}$ Elements Strategy Initiative for Catalysts and Batteries (ESICB), Kyoto University, 1-30 Goryo-Ohara, Nishikyo-ku, Kyoto 615-8245, Japan

${ }^{\mathrm{c}}$ CREST, Japan Science and Technology Agency (JST), 4-1-8 Honcho, Kawaguchi, Saitama 332-0012, Japan

* Corresponding author. Tel: +81-97-554-7895; Fax: +81-97-554-7979

E-mail: nagaoka@oita-u.ac.jp 


\begin{abstract}
Basic oxides such as alkali metal oxides, alkaline earth metal oxides, and rare earth oxides were added to $\mathrm{Ru} / \operatorname{Pr}_{6} \mathrm{O}_{11}$, and the activity of the catalysts with respect to hydrogen production by ammonia decomposition was investigated. $\mathrm{Ru} / \mathrm{Pr}_{6} \mathrm{O}_{11}$ doped with alkali metal oxides, except for $\mathrm{Li}_{2} \mathrm{O}$, achieved higher $\mathrm{NH}_{3}$ conversions than bare $\mathrm{Ru} / \mathrm{Pr}_{6} \mathrm{O}_{11}$. $\mathrm{Cs}_{2} \mathrm{O}$, the most basic of the alkali metal oxides, was the most effective dopant. In contrast, other dopants with lower basicity than the alkali metal oxides achieved lower $\mathrm{NH}_{3}$ conversions than bare $\mathrm{Ru} / \operatorname{Pr}_{6} \mathrm{O}_{11}$. Changing the $\mathrm{Cs} / \mathrm{Ru}$ molar ratio revealed that the best $\mathrm{Cs} / \mathrm{Ru}$ ratio was $0.5-2$; the reaction was effectively promoted without negative effects from coverage of the $\mathrm{Ru}$ surface by the $\mathrm{Cs}_{2} \mathrm{O}$. Varying the order of loading the $\mathrm{Ru}$ and $\mathrm{Cs}_{2} \mathrm{O}$ onto $\mathrm{Pr}_{6} \mathrm{O}_{11}$ revealed that loading $\mathrm{Ru}$ onto $\mathrm{Cs}_{2} \mathrm{O} / \mathrm{Pr}_{6} \mathrm{O}_{11}$ was an effective way to enhance $\mathrm{NH}_{3}$ conversion, and coverage of the $\mathrm{Ru}$ surface was reduced.
\end{abstract}

Keywords:

Hydrogen carrier, Ammonia decomposition, Hydrogen production, $\mathrm{Pr}_{6} \mathrm{O}_{11}$, Ru catalyst, $\mathrm{Cs}_{2} \mathrm{O}$ 


\section{Introduction}

As fossil fuel reserves continue to decrease, the prospects are improving for use of energy from renewable sources, such as the sun and wind [1]. However, the places where renewable energy can be produced are limited, and energy must therefore be stored and transported, for example in the form of hydrogen compounds by a so-called hydrogen carrier [2,3]. Ammonia is regarded as one of the likely hydrogen carriers. Increasing attention is being given to the fact that ammonia may be catalytically decomposed to produce hydrogen, which is then supplied to a proton-exchange membrane fuel cell (PEFC) or to a hydrogen engine. This increasing attention reflects the facts that [4-9] (i) the $\mathrm{H}_{2}$-storage capacity (17.6 wt\%) and energy density (3000 $\mathrm{Whkg}^{-1}$ ) are higher for ammonia than for methanol and other fuels; (ii) ammonia is a liquid at $20{ }^{\circ} \mathrm{C}$ and a pressure of about $0.8 \mathrm{MPa}$, and hence it is easily stored; (iii) $\mathrm{CO}_{2}$, which causes global warming, and $\mathrm{CO}$, which degrades cell electrodes, are not produced when ammonia is converted to hydrogen and nitrogen; and (iv) the concentration of unconverted ammonia can be reduced to less than $200 \mathrm{ppb}$ by using suitable absorbers [10]. Furthermore, ammonia is thermodynamically decomposed at $400{ }^{\circ} \mathrm{C}$ (equilibrium conversion: $99 \%$ ), a temperature at which hydrocarbon steam reforming results in low hydrocarbon conversion and hydrogen yields.

Supported $\mathrm{Ru}$ catalysts doped with basic oxides (i.e., alkali metal oxides) are widely known to be active catalysts for ammonia decomposition [5,11], and GC (graphitic carbon) [11] and CNTs (carbon nanotubes) $[12,13]$ have been reported to be effective carriers of Ru. However, in the cases of on-site generation of hydrogen for PEFCs or use in hydrogen engines, the system is shut down and restarted daily, and catalytic supports that are flammable may not be suitable [14]. In contrast, we have developed highly active Ru catalysts supported on $\mathrm{Pr}_{6} \mathrm{O}_{11}$; these catalysts are highly basic, and their $\mathrm{NH}_{3}$ decomposition activity is greatly enhanced with the addition of $\mathrm{Cs}_{2} \mathrm{O}\left(\mathrm{Cs} / \mathrm{Ru}=1\right.$ in molar ratio) [14]. A Cs $2 \mathrm{O} / \mathrm{Ru} / \operatorname{Pr}_{6} \mathrm{O}_{11}$ catalyst can achieve 
equilibrium $\mathrm{NH}_{3}$ conversion of $99 \%$ at $400{ }^{\circ} \mathrm{C}$, the temperature of which was easily obtained from industrial waste heat.

As mentioned above, compounds with basic characteristics promote ammonia decomposition over $\mathrm{Ru} / \mathrm{Pr}_{6} \mathrm{O}_{11}$ [14]. However, only alkaline metal oxide was used as additives and influence of its loading was not studied. In this study, we therefore examined the effects of basic additives such as alkali metal oxides, alkaline earth metal oxides, and rare earth oxides. The results indicated that the most effective additive was $\mathrm{Cs}_{2} \mathrm{O}$, and we therefore clarified the effect of $\mathrm{Cs}_{2} \mathrm{O}$ by investigating the influence of the $\mathrm{Cs}_{2} \mathrm{O}$ loading and the procedure for preparing the $\mathrm{Ru} / \operatorname{Pr}_{6} \mathrm{O}_{11}$ promoted with $\mathrm{Cs}_{2} \mathrm{O}$.

\section{Materials and Methods}

\subsection{Preparation of catalysts}

Supported Ru catalysts were prepared according to the procedure described in an earlier report [14]. $\operatorname{Pr}_{6} \mathrm{O}_{11}$ supports were precipitated at room temperature from a suspension that was prepared by adding a solution of $\operatorname{Pr}\left(\mathrm{NO}_{3}\right)_{3} \cdot 6 \mathrm{H}_{2} \mathrm{O}$ (Kanto Chemical) to a $25 \mathrm{wt} \% \mathrm{NH}_{3}$ solution. The precipitates were kept in suspension overnight with stirring; they were then filtered, washed with distilled water, dried overnight at $70{ }^{\circ} \mathrm{C}$, and calcined at $700{ }^{\circ} \mathrm{C}$ in static air. The calcined $\operatorname{Pr}_{6} \mathrm{O}_{11}$ was impregnated with $\mathrm{Ru}_{3}(\mathrm{CO})_{12}$ (Tanaka Kikinzoku Kogyo) in a solution of tetrahydrofuran. The Ru loading was set to $5 \mathrm{wt} \%$. The solution was stirred for $12 \mathrm{~h}$, evacuated

in a rotary evaporator, and dried overnight at $70{ }^{\circ} \mathrm{C}$. The precipitate was heated to $350{ }^{\circ} \mathrm{C}$ in He for $5 \mathrm{~h}$ to remove the $\mathrm{CO}$ ligand from the $\mathrm{Ru}_{3}(\mathrm{CO})_{12}$.

$\mathrm{Ru} / \mathrm{Pr}_{6} \mathrm{O}_{11}$ catalysts doped with various oxides were prepared by wet impregnation [14] using $5 \mathrm{wt} \% \mathrm{Ru} / \mathrm{Pr}_{6} \mathrm{O}_{11}$ and aqueous solutions of (i) $\mathrm{CsNO}_{3}$ and $\operatorname{Pr}\left(\mathrm{NO}_{3}\right)_{3}$ purchased from Kanto Chemical Co. Ltd.; (ii) $\mathrm{RbNO}_{3}, \mathrm{KNO}_{3}, \mathrm{NaNO}_{3}, \mathrm{LiNO}_{3}, \mathrm{Ba}\left(\mathrm{NO}_{3}\right)_{2}, \mathrm{Sr}\left(\mathrm{NO}_{3}\right)_{2}, \mathrm{Ca}\left(\mathrm{NO}_{3}\right)_{2}$, 
$\mathrm{Mg}\left(\mathrm{NO}_{3}\right)_{2}, \mathrm{La}\left(\mathrm{NO}_{3}\right)_{3}$, and $\mathrm{Yb}\left(\mathrm{NO}_{3}\right)_{3}$ purchased from Wako Pure Chemical Industries, Ltd.; (iii) $\mathrm{Gd}\left(\mathrm{NO}_{3}\right)_{3}$ purchased from Mitsuwa Chemistry Co., Ltd.; and (iv) $\mathrm{Sm}\left(\mathrm{NO}_{3}\right)_{3}$ purchased from Kishida Chemical Co., Ltd. The molar ratio of these elements to Ru was normally set to 1. However, in the case of $\mathrm{CsNO}_{3}$, the molar ratio of $\mathrm{Cs}$ to $\mathrm{Ru}$ was varied from 0.25 to 5 . These samples were dried at $70{ }^{\circ} \mathrm{C}$ overnight and treated in $\mathrm{H}_{2}$ at $500{ }^{\circ} \mathrm{C}$ for $1 \mathrm{~h}$ to remove $\mathrm{NO}_{3}{ }^{-}$.

For the preparation of $\mathrm{Ru} / \operatorname{Pr}_{6} \mathrm{O}_{11}$ promoted with $\mathrm{Cs}_{2} \mathrm{O}$, another preparation method was also employed. First, $\mathrm{Cs}_{2} \mathrm{O} / \mathrm{Pr}_{6} \mathrm{O}_{11}$ was prepared by wet impregnation using calcined $\operatorname{Pr}_{6} \mathrm{O}_{11}$ and an aqueous solution of $\mathrm{CsNO}_{3}$. This sample was dried at $70{ }^{\circ} \mathrm{C}$ overnight and treated in $\mathrm{H}_{2}$ at $500{ }^{\circ} \mathrm{C}$ for $1 \mathrm{~h}$ to remove $\mathrm{NO}_{3}{ }^{-}$. The $\mathrm{Cs}_{2} \mathrm{O} / \mathrm{Pr}_{6} \mathrm{O}_{11}$ was impregnated with $\mathrm{Ru}_{3}(\mathrm{CO})_{12}$ in a solution of tetrahydrofuran. The solution was stirred, evacuated, and dried overnight at $70{ }^{\circ} \mathrm{C}$. The precipitate was treated in $\mathrm{He}$ at $350{ }^{\circ} \mathrm{C}$ for $5 \mathrm{~h}$. The molar ratio of $\mathrm{Cs}$ to $\mathrm{Ru}$ was fixed at 0.5 .

\subsection{Characterization of catalysts}

The specific surface areas of the catalysts were measured with a BELSORP-mini (BEL Japan, Japan) at $-196{ }^{\circ} \mathrm{C}$ with $\mathrm{N}_{2}$, and the results are listed in Table $\mathrm{S} 1$.

The amount of $\mathrm{CO}$ chemisorbed at $0{ }^{\circ} \mathrm{C}$ (a measure of the number of $\mathrm{Ru}$ atoms on the surface) was determined by pulse methods. The catalysts were treated in situ in $\mathrm{H}_{2}$ at $500{ }^{\circ} \mathrm{C}$ for $1 \mathrm{~h}$ and cooled to $0{ }^{\circ} \mathrm{C}$ in an ice bath under He. At $0{ }^{\circ} \mathrm{C}, \mathrm{CO}$ was pulsed over the catalysts. The amount of CO taken up was measured with a thermal conductivity detector.

\subsection{Tests of catalyst activity}


The procedure for testing activity, which has been described in our earlier report [14], was as follows. Powders of the catalyst were pressed into pellets at $52 \mathrm{MPa}$ for $5 \mathrm{~min}$. They were then crushed and sieved to obtain grains with diameters of 250-500 microns, and an aliquot of 200 $\mathrm{mg}$ of catalyst was loaded into a tubular quartz reactor $(\mathrm{i} . \mathrm{d} .=7 \mathrm{~mm})$. The catalysts were reduced in pure $\mathrm{H}_{2}$ at $500{ }^{\circ} \mathrm{C}$ for $1 \mathrm{~h}$ at a rate of $10{ }^{\circ} \mathrm{C} \mathrm{min}^{-1}$ and then purged with pure $\mathrm{Ar}$ and cooled to $200{ }^{\circ} \mathrm{C}$. At $200{ }^{\circ} \mathrm{C}$, pure $\mathrm{NH}_{3}\left(10 \mathrm{~mL} \mathrm{~min}^{-1}\right.$, space velocity $\left.(\mathrm{SV})=3000 \mathrm{~mL} \mathrm{~h}^{-1} \mathrm{~g}^{-1}\right)$ was passed over the catalyst. The temperature of the catalyst was kept constant for $0.5 \mathrm{~h}$ to measure its activity. The catalyst was then heated by $50{ }^{\circ} \mathrm{C}$. This procedure was repeated until the catalyst had been heated to $500{ }^{\circ} \mathrm{C}$. The reaction products were analyzed by using a gas chromatograph with a thermal conductivity detector (GC-8A, Shimadzu) equipped with an active carbon column.

\section{Results and Discussion}

\subsection{Influence of the kinds of dopants on the decomposition of ammonia over $\mathrm{Ru} / \mathrm{Pr}_{6} \mathrm{O}_{11}$}
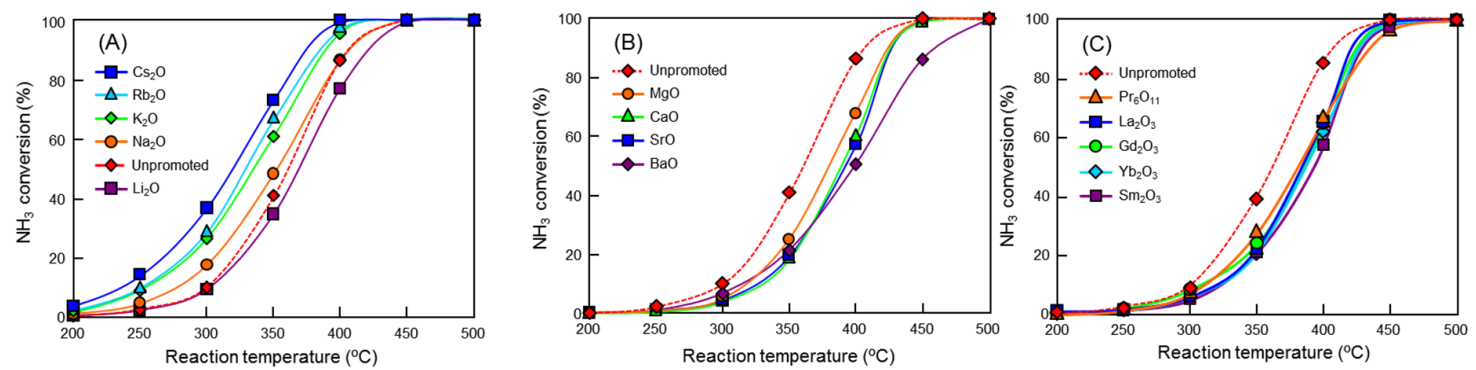

Fig. $1-\mathrm{NH}_{3}$ conversion vs. temperature for $\mathrm{NH}_{3}$ decomposition over 5 wt $\% \mathrm{Ru} / \mathrm{Pr}_{6} \mathrm{O}_{11}$ catalysts doped with (A) alkali metal oxides, (B) alkaline earth metal oxides, and (C) rare earth oxides. 
The $\mathrm{Ru} / \mathrm{Pr}_{6} \mathrm{O}_{11}$ was treated with various kinds of basic oxide dopants. The molar ratio of dopant to $\mathrm{Ru}$ was 1 , and the temperature dependences of the $\mathrm{NH}_{3}$ conversions of the catalysts were compared. First, alkali metal oxides were doped into $\mathrm{Ru} / \operatorname{Pr}_{6} \mathrm{O}_{11}$, and $\mathrm{NH}_{3}$ decomposition activities were measured. The plots, reproduced from our earlier report [14], are shown in Fig. 1A. $\mathrm{Ru} / \mathrm{Pr}_{6} \mathrm{O}_{11}$ doped with alkali metal oxides, except for $\mathrm{Li}_{2} \mathrm{O}$, achieved higher conversions of $\mathrm{NH}_{3}$ than did bare $\mathrm{Ru} / \mathrm{Pr}_{6} \mathrm{O}_{11}$. The difference of $\mathrm{NH}_{3}$ conversion was pronounced at $350{ }^{\circ} \mathrm{C}$ and decreased in the order $\mathrm{Cs}_{2} \mathrm{O}, \mathrm{Rb}_{2} \mathrm{O}, \mathrm{K}_{2} \mathrm{O}$, and $\mathrm{Na}_{2} \mathrm{O}$ as added catalysts. This order was in agreement with the order of the basic nature of the alkali metal oxides; i.e., dopants with stronger basicity promoted ammonia decomposition more effectively.

The effect of doping with alkaline earth metal oxides on the $\mathrm{NH}_{3}$ conversion of $\mathrm{Ru} / \mathrm{Pr}_{6} \mathrm{O}_{11}$ is shown in Fig. 1B. All the catalysts that included alkaline earth metal oxides achieved lower $\mathrm{NH}_{3}$ conversions than bare $\mathrm{Ru} / \mathrm{Pr}_{6} \mathrm{O}_{11}$. Note that with an increase of the basicity of the alkaline earth metal oxides, $\mathrm{NH}_{3}$ conversion decreased. As was the case for $\mathrm{Ru} / \mathrm{Pr}_{6} \mathrm{O}_{11}$ doped with alkaline earth metal oxides, $\mathrm{NH}_{3}$ conversions of $\mathrm{Ru} / \mathrm{Pr}_{6} \mathrm{O}_{11}$ doped with rare earth metal oxides were lower than those achieved with bare $\mathrm{Ru} / \operatorname{Pr}_{6} \mathrm{O}_{11}$ (Fig. 1C).

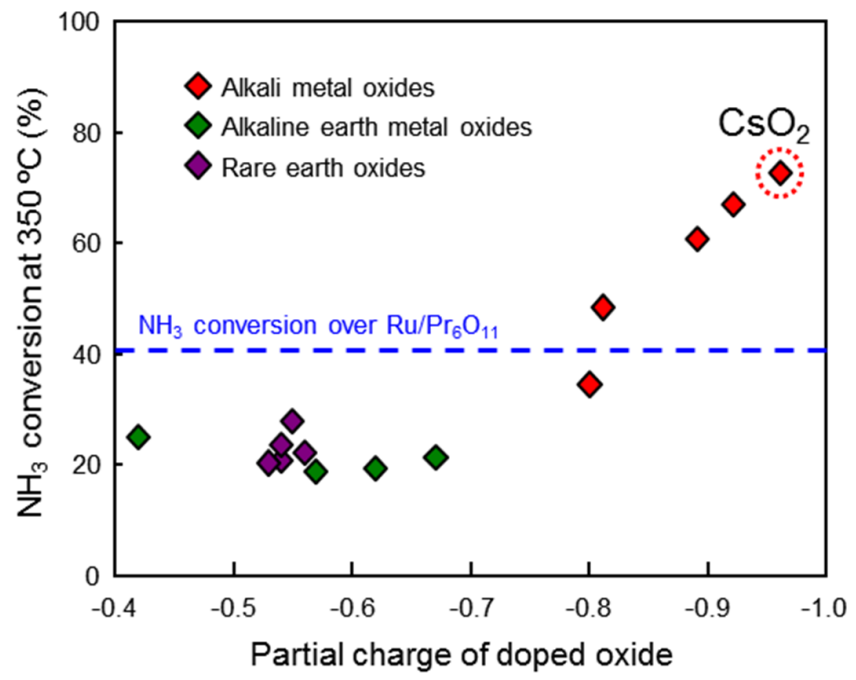

Fig. $2-\mathrm{NH}_{3}$ conversion at $350^{\circ} \mathrm{C}$ for $5 \mathrm{wt} \% \mathrm{Ru} / \mathrm{Pr}_{6} \mathrm{O}_{11}$ doped with various oxides (dopant $/ \mathrm{Ru}$ ratio $=1)$ vs. partial charge of doped oxide. 
To evaluate basicity of the catalyst, we carried out temperature-programmed desorption of ammonia. However, the measurements were not succeeded. This is due to unstable nature of the alkali metal oxide above $350{ }^{\circ} \mathrm{C}$ for $\mathrm{K}_{2} \mathrm{O}, 400{ }^{\circ} \mathrm{C}$ for $\mathrm{Rb}_{2} \mathrm{O}$, and $400{ }^{\circ} \mathrm{C}$ for $\mathrm{Cs}_{2} \mathrm{O}$ [15]. Figure 2 shows $\mathrm{NH}_{3}$ conversions at $350{ }^{\circ} \mathrm{C}$ as a function of the partial charge of the dopants. The partial charge of the oxides is one indicator of the basicity of the oxides [16], and smaller values mean that the oxide is more strongly basic. The values have been successfully used to evaluate basicity of the supported Ru catalysts for ammonia synthesis [17, 18]. Note that partial charge of $\operatorname{Pr}_{6} \mathrm{O}_{11}$ is -0.48 to -0.55 . When the partial charge of the oxide was less than -0.81 , $\mathrm{NH}_{3}$ conversions of the corresponding catalysts were higher than that of bare $\mathrm{Ru} / \operatorname{Pr}_{6} \mathrm{O}_{11}$, and the conversions increased as the partial charge of the oxides decreased. It was therefore apparent that $\mathrm{Ru} / \mathrm{Pr}_{6} \mathrm{O}_{11}$ doped with $\mathrm{Cs}_{2} \mathrm{O}$, which is the strongest base, has the highest activity for $\mathrm{NH}_{3}$ decomposition among the catalysts tested. On the other hand, when the partial charge of the oxide was greater than or equal to -0.8 , the $\mathrm{NH}_{3}$ conversions of the corresponding catalysts were lower than that of bare $\mathrm{Ru} / \operatorname{Pr}_{6} \mathrm{O}_{11}$. Here the catalysts were prepared by wet impregnation of the each nitrate on $\mathrm{Ru} / \mathrm{Pr}_{6} \mathrm{O}_{11}$. Therefore, we assume that part of the $\mathrm{Ru}$ surface was covered by the additives, number of the $\mathrm{Ru}$ active site was deceased, and thus $\mathrm{NH}_{3}$ conversion was decreased.

\subsection{Influence of $\mathrm{Cs} / \mathrm{Ru}$ ratio on the decomposition of ammonia over $\mathrm{Cs}_{2} \mathrm{O} / \mathrm{Ru} / \mathrm{Pr}_{6} \mathrm{O}_{11}$}



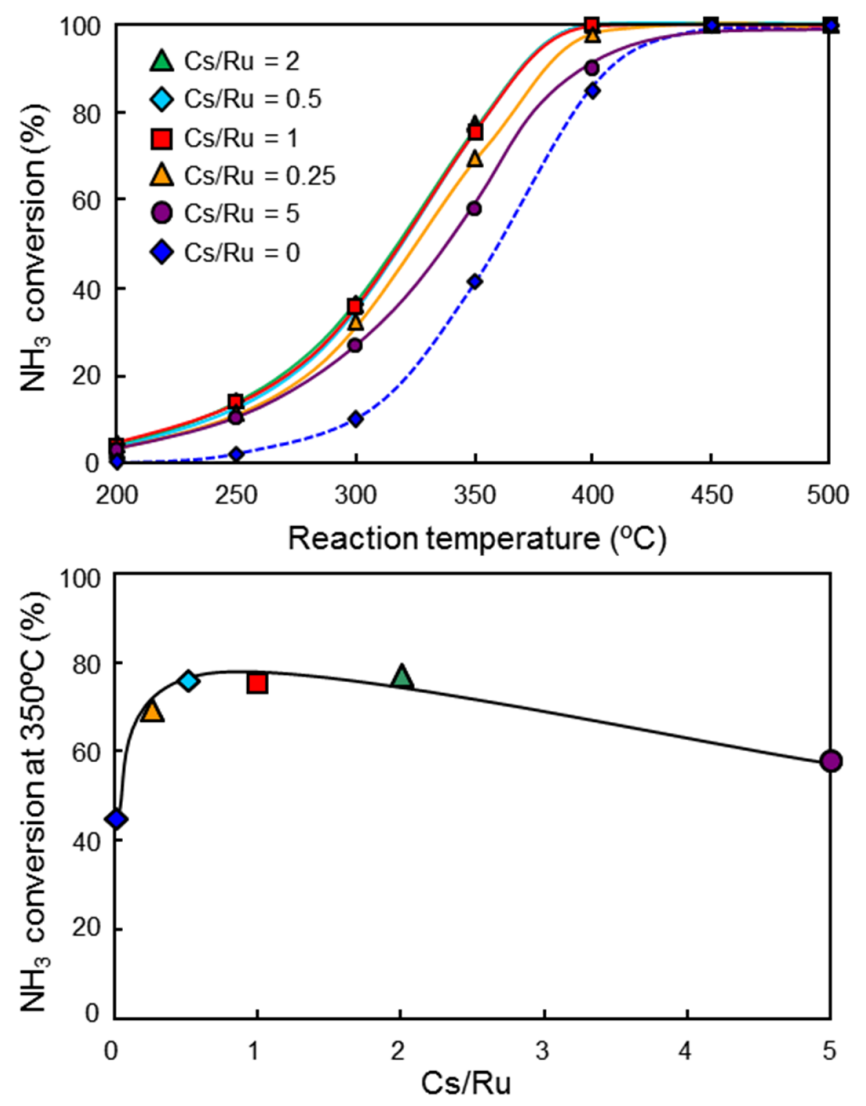

Fig. $3-\mathrm{NH}_{3}$ conversion vs. temperature for $\mathrm{NH}_{3}$ decomposition over $\mathrm{Cs}_{2} \mathrm{O} / 5$ wt $\% \mathrm{Ru} / \mathrm{Pr}_{6} \mathrm{O}_{11}$ with different $\mathrm{Cs} / \mathrm{Ru}$ molar ratios. Lower panel shows $\mathrm{NH}_{3}$ conversion at $350^{\circ} \mathrm{C}$ as a function of the $\mathrm{Cs} / \mathrm{Ru}$ molar ratio.

Different amounts of $\mathrm{Cs}_{2} \mathrm{O}$ were loaded onto $\mathrm{Ru} / \operatorname{Pr}_{6} \mathrm{O}_{11}$, and results of the activity tests are shown in Fig. 3. $\mathrm{NH}_{3}$ conversion over $\mathrm{Ru} / \mathrm{Pr}_{6} \mathrm{O}_{11}$ at $350{ }^{\circ} \mathrm{C}$ increased from $45 \%$ to $76 \%$ with the addition of $\mathrm{Cs}_{2} \mathrm{O}$ at a $\mathrm{Cs} / \mathrm{Ru}$ molar ratio of 0.5 . Further addition of $\mathrm{Cs}_{2} \mathrm{O}$ up to a $\mathrm{Cs} / \mathrm{Ru}$ ratio of 2 had little effect on $\mathrm{NH}_{3}$ conversion. Nevertheless, $\mathrm{Ru} / \mathrm{Pr}_{6} \mathrm{O}_{11}$ doped at a $\mathrm{Cs} / \mathrm{Ru}$ ratio of 5 achieved a lower $\mathrm{NH}_{3}$ conversion of $58 \%$. To understand the cause of the change of $\mathrm{NH}_{3}$ conversion as a function of $\mathrm{Cs} / \mathrm{Ru}$, we performed $\mathrm{CO}$ chemisorption measurements. The $\mathrm{CO} / \mathrm{Ru}$ values are shown in Table 1 . With an increase of the $\mathrm{Cs} / \mathrm{Ru}$ ratio, the $\mathrm{CO} / \mathrm{Ru}$ ratio decreased, but the turnover frequency (TOF) increased. Here $\mathrm{Cs}_{2} \mathrm{O} / \mathrm{Ru} / \mathrm{Pr}_{6} \mathrm{O}_{11}$ was prepared by 
wet impregnation of the $\mathrm{CsNO}_{3}$ on $\mathrm{Ru} / \mathrm{Pr}_{6} \mathrm{O}_{11}$. Therefore this result indicates that part of the $\mathrm{Ru}$ surface was covered by the added $\mathrm{Cs}_{2} \mathrm{O}$, and the covered area of the $\mathrm{Ru}$ surface increased with an increase of the $\mathrm{Cs} / \mathrm{Ru}$ ratio. In contrast, the TOF increased with an increase of the $\mathrm{Cs} / \mathrm{Ru}$ ratio, probably because of an increase in electron donation from $\mathrm{Cs}_{2} \mathrm{O}$ to $\mathrm{Ru}$. It is well known that basic components work as electron donor to $\mathrm{Ru}$, which was proved by decrease in $\mathrm{N}-\mathrm{N}$ stretching frequencies of adsorbed dinitrogen on $\mathrm{Ru}$ with the addition of $\mathrm{Cs}_{2} \mathrm{O}$ to $\mathrm{Ru} / \mathrm{Al}_{2} \mathrm{O}_{3}$ and $\mathrm{Ru} / \mathrm{MgO}[17,18]$. Yin $\mathrm{SF}$ et al. reported the electron donation decreases the apparent activation energy of the $\mathrm{NH}_{3}$ decomposition reaction; this enhances the activity of the $\mathrm{Ru}$ catalyst [5]. Such enhancement of the TOF for $\mathrm{Ru} / \mathrm{Pr}_{6} \mathrm{O}_{11}$ doped at $\mathrm{Cs} / \mathrm{Ru}$ ratios of $0.5-2$ maximized $\mathrm{NH}_{3}$ conversion compared to that of bare $\mathrm{Ru} / \mathrm{Pr}_{6} \mathrm{O}_{11}$, whereas too much coverage of the $\mathrm{Ru}$ surface by $\mathrm{Cs}_{2} \mathrm{O}(\mathrm{Cs} / \mathrm{Ru}=5)$ resulted in a decrease of $\mathrm{NH}_{3}$ conversion.

\begin{tabular}{|c|c|c|c|c|}
\hline Catalyst & Cs/Ru mole ratio & $\mathrm{CO} / \mathrm{Ru}$ & $\begin{array}{l}\text { TOF } \\
\left(\mathbf{s}^{-1}\right)\end{array}$ & $\begin{array}{c}\mathrm{NH}_{3} \text { conversion at } 350^{\circ} \mathrm{C} \\
\left({ }^{\circ} \mathrm{C}\right)\end{array}$ \\
\hline $\mathrm{Cs}_{2} \mathrm{O} / \mathrm{Ru} / \mathrm{Pr}_{6} \mathrm{O}_{11}$ & $\begin{array}{l}0 \\
0.5 \\
5\end{array}$ & $\begin{array}{l}0.33 \\
0.21 \\
0.04\end{array}$ & $\begin{array}{l}0.10 \\
0.27 \\
1.01\end{array}$ & $\begin{array}{l}45 \\
76 \\
58\end{array}$ \\
\hline $\mathrm{Ru} / \mathrm{Cs}_{2} \mathrm{O} / \mathrm{Pr}_{6} \mathrm{O}_{11}$ & 0.5 & 0.24 & 0.30 & 93 \\
\hline
\end{tabular}

\subsection{Influence of the procedure for loading $\mathrm{Cs}_{2} \mathrm{O}$ and $\mathrm{Ru}$ onto $\mathrm{Pr}_{6} \mathrm{O}_{11}$}




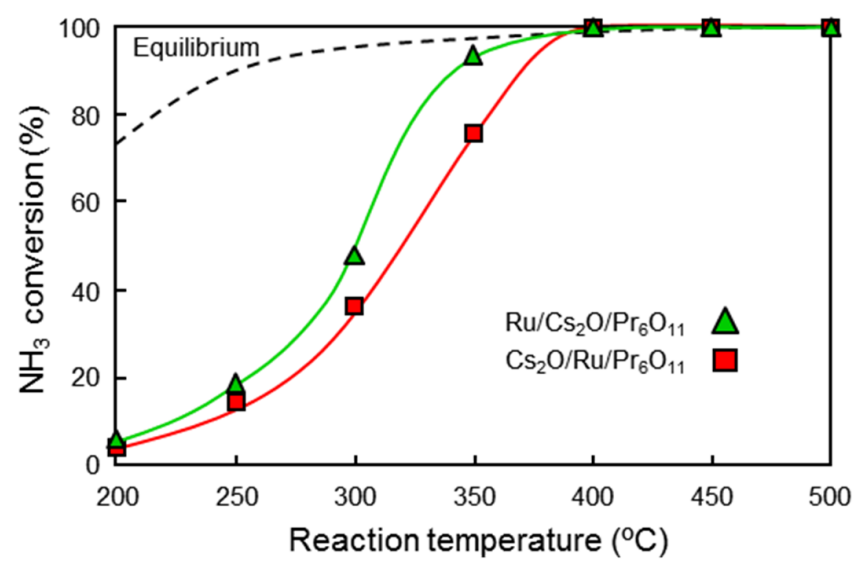

Fig. $4-\mathrm{NH}_{3}$ conversion vs. temperature for $\mathrm{NH}_{3}$ decomposition over $\mathrm{Cs}_{2} \mathrm{O} / \mathrm{Ru} / \operatorname{Pr}_{6} \mathrm{O}_{11}$ and $\mathrm{Ru} / \mathrm{Cs}_{2} \mathrm{O} / \mathrm{Pr}_{6} \mathrm{O}_{11}(\mathrm{Cs} / \mathrm{Ru}$ molar ratio $=0.5)$.

At this point in the study, $\mathrm{Cs}_{2} \mathrm{O}$ had been loaded onto $\mathrm{Ru} / \mathrm{Pr}_{6} \mathrm{O}_{11}$. In this case, $\mathrm{NH}_{3}$ conversion increased because of the effect of electron donation by $\mathrm{Cs}_{2} \mathrm{O}$, but part of the $\mathrm{Ru}$ surface was covered with $\mathrm{Cs}_{2} \mathrm{O}$. To reduce this coverage of the $\mathrm{Ru}$ surface by $\mathrm{Cs}_{2} \mathrm{O}, \mathrm{Cs}_{2} \mathrm{O}$ was first loaded onto $\operatorname{Pr}_{6} \mathrm{O}_{11}$, and $\mathrm{Ru}$ was subsequently loaded onto $\mathrm{Cs}_{2} \mathrm{O} / \operatorname{Pr}_{6} \mathrm{O}_{11}$. It is apparent in Fig. 4 that newly prepared $\mathrm{Ru} / \mathrm{Cs}_{2} \mathrm{O} / \mathrm{Pr}_{6} \mathrm{O}_{11}$ exhibited much higher $\mathrm{NH}_{3}$ conversion than did $\mathrm{Cs}_{2} \mathrm{O} / \mathrm{Ru} / \mathrm{Pr}_{6} \mathrm{O}_{11}$, and the $\mathrm{NH}_{3}$ conversion of the catalyst was $93 \%$ at $350{ }^{\circ} \mathrm{C}$. The $\mathrm{CO} / \mathrm{Ru}$ ratio and TOF at $350{ }^{\circ} \mathrm{C}$ of these catalysts are shown in Table 1 . It is apparent that the $\mathrm{CO} / \mathrm{Ru}$ ratio was improved, and the TOF increased slightly as a result of the change in the preparation procedure, the result being a higher $\mathrm{NH}_{3}$ conversion over $\mathrm{Ru} / \mathrm{Cs}_{2} \mathrm{O} / \mathrm{Pr}_{6} \mathrm{O}_{11}$.

\section{Conclusions}

We prepared $\mathrm{Ru} / \operatorname{Pr}_{6} \mathrm{O}_{11}$ catalysts doped with various kinds of basic oxides and investigated the catalytic activity of the catalysts with respect to ammonia decomposition for renewable 
hydrogen production. $\mathrm{Ru} / \operatorname{Pr}_{6} \mathrm{O}_{11}$ doped with $\mathrm{Cs}_{2} \mathrm{O}$, which is the strongest base, showed the highest $\mathrm{NH}_{3}$ conversion among the catalysts. Changing the ratio of $\mathrm{Cs}$ to $\mathrm{Ru}$ revealed that doping with $\mathrm{Cs}_{2} \mathrm{O}$ enhanced the TOF, but covering only a part of the Ru surface and choice of an appropriate $\mathrm{Cs} / \mathrm{Ru}$ ratio $(0.5-2)$ increased $\mathrm{NH}_{3}$ conversion. Such enhancement of TOF was ascribed to the effect of electron donation to Ru. Furthermore, the preparation procedure was changed from sequential loading of $\mathrm{Cs}_{2} \mathrm{O}$ onto $\mathrm{Ru} / \mathrm{Pr}_{6} \mathrm{O}_{11}$ to sequential loading of $\mathrm{Ru}$ onto $\mathrm{Cs}_{2} \mathrm{O} / \mathrm{Pr}_{6} \mathrm{O}_{11}$. This change enhanced $\mathrm{NH}_{3}$ conversion at $350{ }^{\circ} \mathrm{C}$ over $\mathrm{Ru} / \mathrm{Cs}_{2} \mathrm{O} / \mathrm{Pr}_{6} \mathrm{O}_{11}$ from $76 \%$ to $93 \%$. This enhancement was ascribed to efficient reduction of the area of the Ru surface covered by $\mathrm{Cs}_{2} \mathrm{O}$.

\section{Acknowledgments}

This research was supported by the JSPS KAKENHI (24760641) and JST-CREST. K. Sato thanks the Program for Element Strategy Initiative for Catalysts \& Batteries (ESICB) commissioned by the Ministry of Education, Culture, Sports, Science and Technology (MEXT) of Japan. 


\section{References}

[1] Hayashi F, Toda Y, Kanie Y, Kitano M, Inoue Y, Yokoyama T, et al. Ammonia decomposition by ruthenium nanoparticles loaded on inorganic electride C12A7: - . Chemical Science. 2013;4:3124.

[2] Eberle U, Felderhoff M, Schuth F. Chemical and physical solutions for hydrogen storage. Angew Chem Int Ed Engl. 2009;48:6608-30.

[3] Yang J, Sudik A, Wolverton C, Siegel DJ. High capacity hydrogen storage materials: attributes for automotive applications and techniques for materials discovery. Chem Soc Rev. 2010;39:656-75.

[4] Schüth F, Palkovits R, Schlögl R, Su DS. Ammonia as a possible element in an energy infrastructure: catalysts for ammonia decomposition. Energy \& Environmental Science. 2012;5:6278.

[5] Yin SF, Xu BQ, Zhou XP, Au CT. A mini-review on ammonia decomposition catalysts for on-site generation of hydrogen for fuel cell applications. Appl Catal, A. 2004;277:1-9.

[6] Arana LR, Schaevitz SB, Franz AJ, Schmidt MA, Jensen KF. A microfabricated suspendedtube chemical reactor for thermally efficient fuel processing. Journal of Microelectromechanical Systems. 2003;12:600-12.

[7] Christian, Mitchell M, Kim D, Kenis P. Ceramic microreactors for on-site hydrogen production. J Catal. 2006;241:235-42.

[8] Ganley JC, Seebauer EG, Masel RI. Development of a microreactor for the production of hydrogen from ammonia. J Power Sources. 2004;137:53-61.

[9] Choudhary TV, Sivadinarayana C, Goodman DW. Catalytic ammonia decomposition COxfree hydrogen production for fuel cell applications.pdf. Catal Lett. 2001;72:197-201.

[10] Chellappa AS, Fischer CM, Thomson WJ. Ammonia decomposition kinetics over NiPt/A12O3 for PEM fuel cell applications. Appl Catal, A. 2002;227:231-40.

[11] Li L, Zhu ZH, Yan ZF, Lu GQ, Rintoul L. Catalytic ammonia decomposition over $\mathrm{Ru} /$ carbon catalysts: The importance of the structure of carbon support. Appl Catal, A. 2007;320:166-72.

[12] Chen J, Zhu ZH, Wang S, Ma Q, Rudolph V, Lu GQ. Effects of nitrogen doping on the structure of carbon nanotubes (CNTs) and activity of Ru/CNTs in ammonia decomposition. Chem Eng J. 2010;156:404-10.

[13] Yin SF, Xu BQ, Ng CF, Au CT. Nano Ru/CNTs: a highly active and stable catalyst for the generation of COx-free hydrogen in ammonia decomposition. Appl Catal B-Environ. 2004;48:237-41.

[14] Nagaoka K, Honda K, Ibuki M, Sato K, Takita Y. Highly Active $\mathrm{Cs}_{2} \mathrm{O} / \mathrm{Ru} / \mathrm{Pr}_{6} \mathrm{O}_{11}$ as a Catalyst for Ammonia Decomposition. Chem Lett. 2010;39:918-9. 
[15] The Japan Chemical Society. Kagaku Binran (Handbook of Chemistry), Pure Chemistry $5^{\text {th }}$ ed., Tokyo: Maruzen; 2004.

[16] Sanderson RT. Inorganic Chemistry: REINHOLD PUBLISHING CORPORATION; 1967.

[17] Aika K, Hori H, Ozaki A. Activation of Nitrogen by Alkali Metal Promoted Trnsition Metal I. Ammonia synthesis over Ruthenium ptromoted by alkali metal. 1972;27,424-31

[18] Aika K, Kubota J, Kadowaki Y, Niwa Y, Izumi Y, Molecular sensing techniques for the characterization and design of new ammonia catalysts. Appl. Surf. Sci. 1997, 121/122 48891.

\section{Captions}

Fig. $1-\mathrm{NH}_{3}$ conversion vs. temperature for $\mathrm{NH}_{3}$ decomposition over $5 \mathrm{wt} \% \mathrm{Ru} / \mathrm{Pr}_{6} \mathrm{O}_{11}$ catalysts doped with (A) alkali metal oxides, (B) alkaline earth metal oxides, and (C) rare earth oxides.

Fig. $2-\mathrm{NH}_{3}$ conversion at $350{ }^{\circ} \mathrm{C}$ for $5 \mathrm{wt} \% \mathrm{Ru} / \mathrm{Pr}_{6} \mathrm{O}_{11}$ doped with various oxides $($ dopant $/ \mathrm{Ru}$ ratio $=1)$ vs. partial charge of doped oxide.

Fig. $3-\mathrm{NH}_{3}$ conversion vs. temperature for $\mathrm{NH}_{3}$ decomposition over $\mathrm{Cs}_{2} \mathrm{O} / 5$ wt $\% \mathrm{Ru} / \mathrm{Pr}_{6} \mathrm{O}_{11}$ with different $\mathrm{Cs} / \mathrm{Ru}$ molar ratios. Lower panel shows $\mathrm{NH}_{3}$ conversion at $350{ }^{\circ} \mathrm{C}$ as a function of the $\mathrm{Cs} / \mathrm{Ru}$ molar ratio.

Fig. $4-\mathrm{NH}_{3}$ conversion vs. temperature for $\mathrm{NH}_{3}$ decomposition over $\mathrm{Cs}_{2} \mathrm{O} / \mathrm{Ru} / \mathrm{Pr}_{6} \mathrm{O}_{11}$ and $\mathrm{Ru} / \mathrm{Cs}_{2} \mathrm{O} / \mathrm{Pr}_{6} \mathrm{O}_{11}(\mathrm{Cs} / \mathrm{Ru}$ molar ratio $=0.5)$.

Table 1 - Results of $\mathrm{CO}$ chemisorption and activity tests for supported $\mathrm{Ru} / \mathrm{Pr}_{6} \mathrm{O}_{11}$ and $\mathrm{Ru} / \mathrm{Pr}_{6} \mathrm{O}_{11}$ doped with $\mathrm{Cs}_{2} \mathrm{O}$ 